\title{
Adrenocortical development and cancer: focus on SF-1
}

\author{
Enzo Lalli ${ }^{1,2}$ \\ ${ }^{1}$ Institut de Pharmacologie Moléculaire et Cellulaire, CNRS UMR 6097, 660 route des Lucioles, Sophia Antipolis, 06560 Valbonne, France \\ ${ }^{2}$ Université de Nice, Sophia Antipolis, 06560 Valbonne, France \\ (Correspondence should be addressed to E Lalli at Institut de Pharmacologie Moléculaire et Cellulaire, CNRS UMR 6097; Email: ninino@ipmc.cnrs.fr)
}

\begin{abstract}
Steroidogenic factor-1 (SF-1/Ad4-binding protein; NR5A1) is an essential regulator of tissue-specific gene expression in steroidogenic cells and of adrenogonadal development. Here, I discuss recent data in the literature showing the implication of SF-1 and the importance of its dosage not only during development but also for adrenal cortex tumorigenesis in humans and mice.
\end{abstract}

Journal of Molecular Endocrinology (2010) 44, 301-307

\section{Introduction}

The story of steroidogenic factor-1 (SF-1, also termed Ad4-binding protein, Ad4BP; NR5A1 in nuclear receptors' official nomenclature) began in 1992 with the cloning by the Parker and Morohashi groups of a transcription factor that binds to and activates transcription from multiple P450 steroidogenic enzyme promoters (Lala et al. 1992, Morohashi et al. 1992). This factor turned out to be the homolog of Drosophila melanogaster FTZ-F1, a member of the nuclear receptor family which regulates the expression of the pair rule homeodomain transcription factor fushi tarazu. SF-1 binds as a monomer to nuclear receptor half sites on DNA (Wilson et al. 1993). Its transcriptional activity can be regulated by putative phospholipid ligands that bind inside its hydrophobic pocket (Krylova et al. 2005, Li et al. 2005, Wang et al. 2005), and by post-translational modifications, namely phosphorylation by different kinases at Ser203 (Hammer et al. 1999, Lewis et al. 2008) and sumoylation, which may affect subnuclear localization of SF-1 and its DNA-binding activity (Chen et al. 2004, Komatsu et al. 2004, Lee et al. 2005, Campbell et al. 2008).

\section{An essential actor in adrenogonadal development}

The demonstration of the pivotal role of SF-1 in adrenogonadal development came from $S f$-1-null mice, which have no adrenal glands nor gonads at birth (Luo et al. 1994, Sadovsky et al. 1995). Interestingly, adrenal and gonadal development initiates normally in Sf-1-null mice, but then their primordia regress by apoptosis starting from embryonic day 12 (E12.0; Luo et al. 1994).

During development, gonads and adrenals are derived from a common precursor structure, the adrenogonadal primordium, located between the coelomic epithelium of the urogenital ridge and the dorsal aorta. This primordium is evidenced as early as E9 in mice. Afterwards, the adrenal and gonadal anlage progressively become distinct, which is well recognizable by E13. Primordial germ cells colonize the (at the time still sexually undifferentiated) gonadal anlage by E10. The bipotent gonad differentiates into a testis or into an ovary after E11.5-E12, when the Sry testisdetermining gene starts to be expressed. The adrenal primordium is progressively colonized by cells originating from the neural crest that will later form the adrenal medulla. In mice, the adrenal cortex and medulla become distinct by E16.

SF-1 expression pattern during development is restricted to tissues involved in steroidogenesis (adrenal cortex, testis, and ovary) and reproductive function (pituitary gonadotropes and hypothalamic ventromedial nucleus; Ikeda et al. 1994), plus the spleen (Morohashi et al. 1999). This pattern is strikingly similar to the pattern of expression of Dax-1 (Nr0b1), another nuclear receptor that works as a negative regulator of SF-1 (Ikeda et al. 1996). SF-1 starts to be detected at E9 in the adrenogonadal primordium (being a useful marker for it; see Hatano et al. 1996), and continues 
thereafter to be expressed in both the embryonal adrenal and gonad after their individualization. When the adrenal cortex and medulla separate, SF-1 expression localizes to the cortical region and remains expressed in this portion of the gland until adulthood. One study reported a transient down-regulation of SF-1 expression in the mouse adrenal after E18.5 and until postnatal day 6 (Martinez et al. 2003).

Until recently, only factors regulating SF-1 expression in extra-adrenal sites were known. An E-box-binding site within the basal promoter of the gene is critical for SF-1 expression (Nomura et al. 1995), and the transcription factor POD1/capsulin was shown to suppress SF-1 expression in the gonad through binding to the E-box (Tamura et al. 2001, Cui et al. 2004), while WT1 has a positive role in SF-1 expression in the developing gonad (Wilhelm \& Englert 2002), similarly to the LIM homeobox gene $L h x 9$ (Birk et al. 2000). In addition, a conserved distal enhancer in intron 6 of the $S f-1$ gene is important for its VMH-specific expression (Shima et al. 2005). More recently, elegant studies from K Morohashi's group have elucidated the mechanisms leading to SF-1 expression in the developing mouse adrenal. By the use of transgenic mice, the existence of a fetal adrenal enhancer (FAdE) has been defined in intron 4 of the $S f-1$ gene locus, which drives SF-1 expression in the fetal, but not in the adult, adrenal. Importantly, binding sites for the homeodomain factors $\mathrm{Pbx} /$ Prep and $\mathrm{Pbx} / \mathrm{Hox}$ in the FAdE are required to initiate the establishment of SF-1 expression in the mouse fetal adrenal, while thereafter SF-1 maintains its own expression through an autoregulatory loop binding to sites inside the FAdE (Zubair et al. 2006). Further lineage-tracing studies demonstrated that the adult adrenal cortex in mice derives from precursor cells in the fetal cortex in which the FAdE was activated during early development. However, the ability of precursor cells that activate the FAdE to contribute to the adult adrenal cortex largely disappears by E14.5 (Zubair et al. 2008). After birth, fetal zone cells where the FAdE is active are restricted to the X-zone, a transient zone of the mouse adrenal cortex which is located in an innermost position and regresses at puberty in the males and after the first pregnancy in the females (Zubair et al. 2006). Interestingly, during adrenal development, the expression of the SF-1 repressor DAX-1 localizes in the outer part of the adrenal primordium (the zone that will later give rise to the adult adrenal cortex), while FadE-dependent expression of SF-1 progressively restricts to the inner part of the adrenal cortex (Zubair et al. 2008). This suggests that DAX-1 represses expression of SF-1 driven by its FAdE during the transition from the fetal to the adult adrenal, and that a subtle balance between SF-1 and DAX-1 is required for execution of the full genetic program needed for adrenal development.
$D A X-1$ mutations in humans in fact cause adrenal hypoplasia congenita, an adrenocortical hormone deficiency syndrome caused by a defect of adrenal development (Zanaria et al. 1994).

\section{Dosage at the core of SF-1 biological activity}

A critical factor to be considered when examining the role of SF-1 during development is its dosage. The first clue about the importance of SF-1 dosage for its biological activity came from the description of a patient with adrenal failure and complete $46, \mathrm{XY}$ sex reversal bearing a heterozygous loss-of-function SF-1 mutation (G35E; Achermann et al. 1999). Afterwards, several other patients have been described where SF-1 haploinsufficiency causes variable degrees of gonadal and adrenal dysgenesis (Jameson 2004). To date, only one homozygous SF-1 mutation has been described (R92Q) in a patient with adrenal hypoplasia and 46,XY sex reversal. This mutation reduces SF-1 transcriptional activity only partially, consistent with its phenotypic expression only when transmitted as a homozygous trait (Achermann et al. 2002). Notably, in humans, gonadal development appears to be more sensitive to SF-1 haploinsufficiency than adrenal development (Lin \& Achermann 2008). Conversely, $S f-1$ heterozygote mice have smaller adrenal glands and higher evening ACTH levels than wild-type mice, displaying a condition of latent adrenal insufficiency that becomes overt under stressful stimulations (Bland et al. 2000; Fig. 1). While gonads are also smaller in $S f-1$ heterozygote mice (Bland et al. 2000), these animals are fertile (Luo et al. 1994). Furthermore, the presence of two $S f-1$ copies is critical for producing adrenal hypertrophy and hyperplasia in a model of postnatal adrenal growth following unilateral adrenalectomy (Beuschlein et al. 2002). Modulation of SF-1 dosage is also relevant for the mechanism of adrenal development impairment induced by the lack of CITED2, a transcriptional cofactor supposedly interacting with WT1 (Val et al. 2007). On the other hand, transgenic overexpression of SF-1 in mice under the control of its own FAdE led to increased adrenal size and to the formation of ectopic adrenal tissue in the thorax (Zubair et al. 2009). All together, these data evidence the importance of SF-1 dosage for both adrenal and gonadal development.

\section{SF-1 dosage and adrenocortical tumorigenesis in humans}

Adrenocortical tumors (ACTs) in children are in many cases diagnosed in the context of multiorgan cancer syndromes, but they can also occur sporadically (Koch et al. 2002). Their incidence is highest during 


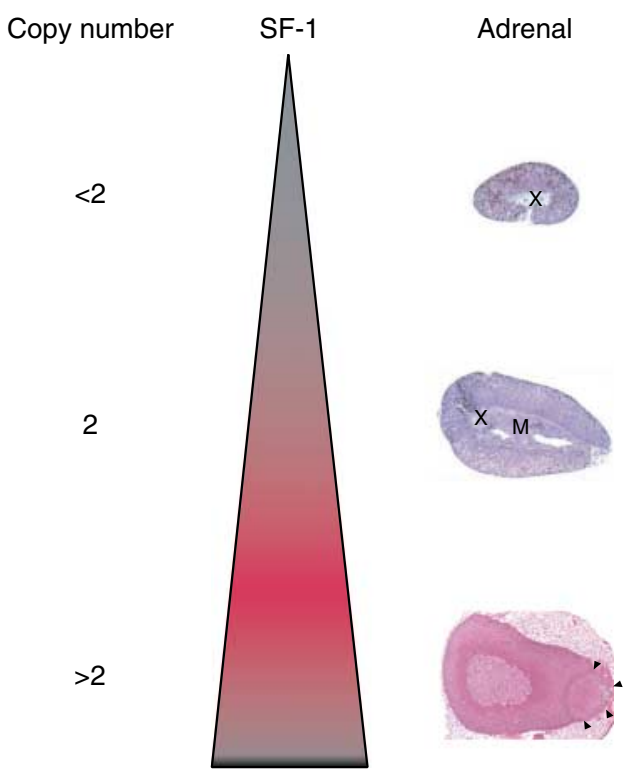

Figure 1 Effect of SF-1 dosage on mouse adrenal gland development and tumorigenesis. SF-1 haploinsufficiency causes adrenal hypoplasia and latent insufficiency, while normal adrenal development ensues in the presence of two normal Sf-1 alleles. Increased SF-1 dosage by transgenic overexpression causes tumor formation (arrowheads) in the adrenal cortex. X, X-zone; $M$, medulla. Scale bar, $200 \mu \mathrm{m}$. Images are reproduced with permission from Bland et al. (2000) (Copyright 2000, National Academy of Sciences, USA) and Doghman et al. (2007a) (Copyright 2007, The Endocrine Society).

the first 3 years of life. Epidemiologically, it is remarkable that these tumors are much more frequent in Southern Brazil than in the rest of the world. Overall, their response to therapy is still poor, with 5-year survival rates that range at $50 \%$ (Michalkiewicz et al. 2004). In Southern Brazil, childhood ACTs are found to be associated with a specific low-penetrance germline mutation of tumor protein p53 (TP53), leading to the substitution of arginine with histidine at codon 337 (Ribeiro et al. 2001, Figueiredo et al. 2006). The diagnosis of childhood ACTs is most frequently made because of symptoms associated with hormone excess. Virilization is the most common sign, and in several cases, it is associated with Cushing's syndrome. These tumors are believed to be derived from the fetal adrenal because of their early age of onset, their pattern of hormone secretion, and their very high insulin-like growth factor 2 expression (Wilkin et al. 2000). Using comparative genomic hybridization (CGH), it has been shown that childhood ACTs are characterized by a high frequency of chromosomal aberrations. It is remarkable that the gain/amplification of 9q33-q34 emerged as the most consistent finding in a great majority of cases of childhood ACTs (Figueiredo et al. 1999). This chromosomal region harbors the human SF-1 gene, which is indeed amplified and overexpressed in childhood ACTs (Figueiredo et al. 2005, Pianovski et al. 2006). Considering the pivotal function of SF-1 in adrenal gland development, we hypothesized that its increased dosage might play an important role in ACT tumorigenesis. Using the H295R human adrenocortical cell model, we showed that SF-1 overexpression significantly increases proliferation through combined effects on cell cycle progression and apoptosis (Doghman et al. 2007b). Importantly, this effect is dependent on the transcriptional activity of the factor, since overexpression of an activation function-2 (AF-2) mutant does not trigger an increase in cell proliferation.

Increased SF-1 levels selectively modulate steroidogenic enzyme expression and the pattern of steroids secreted by H295R cells, with reduction of cortisol and aldosterone and maintenance of dehydroepiandrosterone-sulfate (DHEA-S) production. SF-1 overexpression in human ACT cells has a significant impact on the expression of genes involved in steroid metabolism, cell cycle, apoptosis, and cell adhesion (Doghman et al. 2007a). An increased SF-1 dosage in ACT cells can reproduce several molecular features of childhood ACTs, where some enzymes implicated in steroid metabolism (HSD3B2 and CYP21A2) are also down-regulated (West et al. 2007). NOV/CCN3 is one of the most significantly repressed transcripts in childhood ACTs compared with normal adrenal cortex. This is a secreted multimodular protein whose expression was described to be mostly restricted to the definitive zone of the fetal adrenal cortex (Ratcliffe et al. 2003). NOV/CCN3 is down-regulated in childhood ACTs, independently from their degree of malignancy, and in human adrenocortical cells in a manner dependent on SF-1 dosage. Moreover, NOV/CCN3 is a selective proapoptotic factor for human adrenocortical cells (Doghman et al. 2007a). These properties suggest that this factor may have an important role during adrenal development and oncogenesis.

\section{SF-1 dosage and ACTs in mice}

ACTs can occur after gonadectomy in certain rodent species, including mice (reviewed by Bielinska $e t$ al. (2006)). Remarkably, only certain inbred (e.g. C3H and DBA/2J) or transgenic (inhibin $\alpha$-null mice/inhibin $\alpha$ promoter-SV40 T-antigen transgenic mice) mouse strains are susceptible to gonadectomy-induced ACT formation (Matzuk et al. 1994, Kananen et al. 1996, Rilianawati et al. 1998, Bielinska et al. 2003, 2005, Johnsen et al. 2006). One major genomic locus implicated in gonadectomy-induced adrenocortical tumorigenesis has been mapped on chromosome 8, which is modulated by epistasis by another quantitative trait locus on chromosome 18 (Bernichtein et al. 2008). 


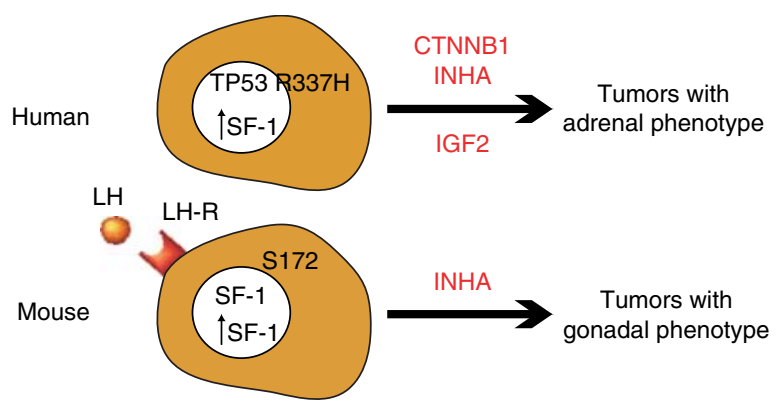

Adrenogonadal pluripotent precursor cells

Figure 2 A model for the implication of an increased SF-1 dosage in adrenocortical tumorigenesis in humans and mice. In childhood adrenocortical tumors (top), increased SF-1 dosage in the presence of a germline TP53 mutation with loss of heterozygosity in the tumor would trigger proliferation of adrenocortical cells around the period of physiological fetal adrenal regression. Other genetic lesions (e.g. inhibin- $\alpha$ and $\beta$-catenin mutations, and IGF2 overexpression) may participate in the tumorigenic process. In mice (bottom), adrenocortical tumors may arise after gonadectomy in certain susceptible strains, which develop gonadal-type tumors. These tumors arise under the control of pituitary LH from adrenogonadal precursor cells residing in the subcapsular region of the adrenal cortex. Notably, susceptible strains harbor the $S f-1^{S 172}$ allele, which may predispose to increased expression, or lack the tumor suppressor inhibin- $\alpha$. The same effect is produced by increased Sf-1 levels in the C57/B6 background in the absence of elevated gonadotropin levels. CTNNB1, $\beta$-catenin; INHA, inhibin- $\alpha$. Adapted with the permission of Doghman \& Lalli (2009); Elsevier Masson, Editor.

Neoplastic cells in these tumors express gonadal markers, and their growth is dependent upon the high levels of circulating gonadotropins present after gonadectomy. Recent studies have demonstrated the origin of these tumors from pluripotent adrenogonadal precursor cells situated in a subcapsular position in the adrenal cortex, which retain the potential to differentiate into cells harboring features of gonadal stroma (Looyenga \& Hammer 2006).

The spatiotemporal expression of the endogenous $S f-1$ gene can be recapitulated in YAC transgenic mice carrying the rat $S f-1$ gene locus (Karpova et al. 2005). Several transgenic lines were generated, each one of which carried a different transgene copy number. In each case, $S f-1$ overexpression triggered adrenocortical tumorigenesis (Doghman et al. 2007b; Fig. 1). Remarkably, tumors arising in $S f-1$ transgenic mice histologically resemble granulosa cell tumors and express gonadal markers such as Amh and Gata-4, while they do not express the steroidogenic enzyme P450scc (Doghman et al. 2007b). As such, this closely matches the phenotype of ACTs occurring in some strains of mice after gonadectomy. These data show that in both humans and mice, SF-1 acts as an important regulator of ACT cell proliferation, even if profound differences exist in the phenotype of ACTs in the two species
(Fig. 2). For this reason and also because of its restricted pattern of expression, SF-1 represents an appealing therapeutic target in childhood ACTs. Compounds able to block SF-1 transcriptional activity have been identified (Del Tredici et al. 2008, Madoux et al. 2008), and we have recently shown that SF-1 inverse agonists of the isoquinolinone class are able to reverse the effect of increased SF-1 dosage on proliferation of the H295R ACT cell line (Doghman et al. 2009). These data suggest the potential clinical utility of molecules targeting SF-1 in the therapy of advanced childhood ACTs.

In adult ACTs, some CGH studies also showed frequent amplification of the region harboring the $S F$ 1 gene (Dohna et al. 2000). Different authors have described variable expression of SF-1 mRNA or protein. While some studies reported similar SF-1 levels in normal adrenal compared to cortisol-producing adenomas (Sasano et al. 1995, Shibata et al. 2001) and in adrenocortical adenomas and carcinomas (Kiiveri et al. 2005), others described increased SF-1 mRNA expression in aldosterone- and cortisol-producing adenomas (Bassett et al. 2005), and in adenomas relative to carcinomas (Lefrançois-Martinez et al. 2004). Possible explanations for these discrepancies are differences between the methods used to measure SF-1 expression at the mRNA or protein level. Furthermore, one has to consider that SF-1 activity in adrenocortical cells also depends on the relative abundance of its repressors (e.g. DAX-1 and COUP$\mathrm{TF})$, and on its post-translational modifications and availability of putative activating ligands. For these reasons, further studies are required to assess whether an increased SF-1 activity may be involved in the pathogenesis of ACTs in adults.

\section{Declaration of interest}

The authors declare that there is no conflict of interest that could be perceived as prejudicing the impartiality of the research reported.

\section{Funding}

This research did not receive any specific grant from any funding agency in the public, commercial, or not-for-profit sector.

\section{Acknowledgements}

This paper is dedicated to the memory of Dr Keith L Parker (19542008) for his pioneering work in the field of molecular regulation of steroidogenesis. 


\section{References}

Achermann JC, Ito M, Ito M, Hindmarsh PC \& Jameson JL 1999 A mutation in the gene encoding steroidogenic factor-1 causes XY sex-reversal and adrenal failure in humans. Nature Genetics $\mathbf{2 2}$ 125-126.

Achermann JC, Ozisik G, Ito M, Orun UA, Harmanci K, Gurakan B \& Jameson JL 2002 Gonadal determination and adrenal development are regulated by the orphan nuclear receptor steroidogenic factor1 , in a dose-dependent manner. Journal of Clinical Endocrinology and Metabolism 87 1829-1833.

Bassett MH, Mayhew B, Rehman K, White PC, Mantero F, Arnaldi G, Stewart PM, Bujalska I \& Rainey WE 2005 Expression profiles for steroidogenic enzymes in adrenocortical disease. Journal of Clinical Endocrinology and Metabolism 90 5446-5455.

Bernichtein S, Petretto E, Jamieson S, Goel A, Aitman TJ, Mangion JM \& Huhtaniemi IT 2008 Adrenal gland tumourigenesis after gonadectomy in mice is a complex genetic trait driven by epistatic loci. Endocrinology 149 651-661.

Beuschlein F, Mutch C, Bavers DL, Ulrich-Lai YM, Engeland WC, Keegan C \& Hammer GD 2002 Steroidogenic factor-1 is essential for compensatory adrenal growth following unilateral adrenalectomy. Endocrinology 143 3122-3135.

Bielinska M, Parviainen H, Porter-Tinge SB, Kiiveri S, Genova E, Rahman N, Huhtaniemi IT, Muglia LJ, Heikinheimo M \& Wilson DB 2003 Mouse strain susceptibility to gonadectomy-induced adrenocortical tumour formation correlates with the expression of GATA-4 and luteinizing hormone receptor. Endocrinology 144 4123-4133.

Bielinska M, Genova E, Boime I, Parviainen H, Kiiveri S, Leppaluoto J, Rahman N, Heikinheimo M \& Wilson DB 2005 Gonadotropininduced adrenocortical neoplasia in NU/J nude mice. Endocrinology 146 3975-3984.

Bielinska M, Kiiveri S, Parviainen H, Mannisto S, Heikinheimo M \& Wilson DB 2006 Gonadectomy-induced adrenocortical neoplasia in the domestic ferret (Mustela putorius furo) and laboratory mouse. Veterinary Pathology 43 97-117.

Birk OS, Casiano DE, Wassif CA, Cogliati T, Zhao L, Zhao Y, Grinberg A, Huang S, Kreidberg JA, Parker KL et al. 2000 The LIM homeobox gene Lhx9 is essential for mouse gonad formation. Nature 403 909-913.

Bland ML, Jamieson CA, Akana SF, Bornstein SR, Eisenhofer G, Dallman MF \& Ingraham HA 2000 Haploinsufficiency of steroidogenic factor 1 in mice disrupts adrenal development leading to an impaired stress response. PNAS 97 14488-14893.

Campbell LA, Faivre EJ, Show MD, Ingraham JG, Flinders J, Gross JD \& Ingraham HA 2008 Decreased recognition of SUMO-sensitive target genes following modification of SF-1 (NR5A1). Molecular and Cellular Biology 28 7476-7486.

Chen WY, Lee WC, Hsu NC, Huang F \& Chung BC 2004 SUMO modification of repression domains modulates function of nuclear receptor 5A1 (steroidogenic factor-1). Journal of Biological Chemistry 279 38730-38735.

Cui S, Ross A, Stallings N, Parker KL, Capel B \& Quaggin SE 2004 Disrupted gonadogenesis and male-to-female sex reversal in Pod1 knockout mice. Development 131 4095-4105.

Del Tredici AL, Andersen CB, Currier EA, Ohrmund SR, Fairbain LC, Lund BW, Nash N, Olsson R \& Piu F 2008 Identification of the first synthetic steroidogenic factor 1 inverse agonists: pharmacological modulation of steroidogenic enzymes. Molecular Pharmacology 73 900-908.

Doghman M \& Lalli E 2009 A matter of dosage: SF-1 in adrenocortical development and cancer. Annales d'Endocrinologie 70 148-152.

Doghman M, Arhatte M, Thibout H, Rodrigues G, De Moura J, Grosso S, West AN, Laurent M, Mas JC, Bongain A et al. $2007 a$ Nephroblastoma overexpressed/cysteine-rich protein 61/connective tissue growth factor/nephroblastoma overexpressed gene-3
(NOV/CCN3), a selective adrenocortical cell proapoptotic factor, is down-regulated in childhood adrenocortical tumours. Journal of Clinical Endocrinology and Metabolism 92 3253-3260.

Doghman M, Karpova T, Rodrigues GA, Arhatte M, De Moura J, Cavalli LR, Virolle V, Barbry P, Zambetti GP, Figueiredo BC et al. $2007 b$ Increased steroidogenic factor-1 dosage triggers adrenocortical cell proliferation and cancer. Molecular Endocrinology 21 2968-2987.

Doghman M, Cazareth J, Douguet D, Madoux F, Hodder P \& Lalli E 2009 Inhibition of adrenocortical carcinoma cell proliferation by steroidogenic factor-1 inverse agonists. Journal of Clinical Endocrinology and Metabolism 94 2178-2183.

Dohna M, Reincke M, Mincheva A, Allolio B, Solinas-Toldo S \& Lichter P 2000 Adrenocortical carcinoma is characterized by a high frequency of chromosomal gains and high-level amplifications. Genes, Chromosomes and Cancer 28 145-152.

Figueiredo BC, Stratakis CA, Sandrini R, DeLacerda L, Pianovski MA, Giatzakis C, Young HM \& Haddad BR 1999 Comparative genomic hybridization analysis of adrenocortical tumours of childhood. Journal of Clinical Endocrinology and Metabolism $\mathbf{8 4}$ 1116-1121.

Figueiredo BC, Cavalli LR, Pianovski MA, Lalli E, Sandrini R, Ribeiro RC, Zambetti G, DeLacerda L, Rodrigues GA \& Haddad BR 2005 Amplification of the steroidogenic factor 1 gene in childhood adrenocortical tumours. Journal of Clinical Endocrinology and Metabolism 90 615-619.

Figueiredo BC, Sandrini R, Zambetti GP, Pereira RM, Cheng C, Liu W, Lacerda L, Pianovski MA, Michalkiewicz E, Jenkins J et al. 2006 Penetrance of adrenocortical tumours associated with the germline TP53 R337H mutation. Journal of Medical Genetics 43 91-96.

Hammer GD, Krylova I, Zhang Y, Darimont BD, Simpson K, Weigel NL \& Ingraham HA 1999 Phosphorylation of the nuclear receptor SF-1 modulates cofactor recruitment: integration of hormone signaling in reproduction and stress. Molecular Cell 3 521-526.

Hatano O, Takakusu A, Nomura M \& Morohashi K 1996 Identical origin of adrenal cortex and gonad revealed by expression profiles of Ad4BP/SF-1. Genes to Cells 1 663-671.

Ikeda Y, Shen WH, Ingraham HA \& Parker KL 1994 Developmental expression of mouse steroidogenic factor-1, an essential regulator of the steroid hydroxylases. Molecular Endocrinology 8 654-662.

Ikeda Y, Swain A, Weber TJ, Hentges KE, Zanaria E, Lalli E, Tamai KT, Sassone-Corsi P, Lovell-Badge R, Camerino G et al. 1996 Steroidogenic factor 1 and Dax-1 colocalize in multiple cell lineages: potential links in endocrine development. Molecular Endocrinology 10 1261-1272.

Jameson JL 2004 Of mice and men: the tale of steroidogenic factor-1. Journal of Clinical Endocrinology and Metabolism 89 5927-5929.

Johnsen IK, Slawik M, Shapiro I, Hartmann MF, Wudy SA, Looyenga BD, Hammer GD, Reincke M \& Beuschlein F 2006 Gonadectomy in mice of the inbred strain CE/J induces proliferation of subcapsular adrenal cells expressing gonadal marker genes. Journal of Endocrinology 190 47-57.

Kananen K, Markkula M, Mikola M, Rainio EM, McNeilly A \& Huhtaniemi I 1996 Gonadectomy permits adrenocortical tumourigenesis in mice transgenic for the mouse inhibin $\alpha$-subunit promoter/simian virus $40 \mathrm{~T}$-antigen fusion gene: evidence for negative autoregulation of the inhibin a-subunit gene. Molecular Endocrinology 10 1667-1677.

Karpova T, Presley J, Manimaran RR, Scherrer SP, Tejada L, Peterson KR \& Heckert LL 2005 A Ftz-F1-containing yeast artificial chromosome recapitulates expression of steroidogenic factor 1 in vivo. Molecular Endocrinology 19 2549-2563.

Kiiveri S, Liu J, Arola J, Heikkila P, Kuulasmaa T, Lehtonen E, Voutilainen R \& Heikinheimo M 2005 Transcription factors GATA-6, SF-1, and cell proliferation in human adrenocortical tumors. Molecular and Cellular Endocrinology 233 47-56. 
Koch CA, Pacak K \& Chrousos GP 2002 The molecular pathogenesis of hereditary and sporadic adrenocortical and adrenomedullary tumours. Journal of Clinical Endocrinology and Metabolism 87 $5367-5384$.

Komatsu T, Mizusaki H, Mukai T, Ogawa H, Baba D, Shirakawa M, Hatakeyama S, Nakayama KI, Yamamoto H, Kikuchi A et al. 2004 Small ubiquitin-like modifier 1 (SUMO-1) modification of the synergy control motif of Ad4 binding protein/steroidogenic factor 1 (Ad4BP/SF-1) regulates synergistic transcription between Ad4BP/SF-1 and Sox9. Molecular Endocrinology 18 2451-2462.

Krylova IN, Sablin EP, Moore J, Xu RX, Waitt GM, MacKay JA, Juzumiene D, Bynum JM, Madauss K, Montana V et al. 2005 Structural analyses reveal phosphatidyl inositols as ligands for the NR5 orphan receptors SF-1 and LRH-1. Cell 120 343-355.

Lala DS, Rice DA \& Parker KL 1992 Steroidogenic factor I, a key regulator of steroidogenic enzyme expression, is the mouse homolog of fushi tarazu-factor I. Molecular Endocrinology 6 1249-1258.

Lee MB, Lebedeva LA, Suzawa M, Wadekar SA, Desclozeaux M \& Ingraham HA 2005 The DEAD-box protein DP103 (Ddx20 or Gemin-3) represses orphan nuclear receptor activity via SUMO modification. Molecular and Cellular Biology 25 1879-1890.

Lefrançois-Martinez AM, Bertherat J, Val P, Tournaire C, Gallo-Payet N, Hyndman D, Veyssiere G, Bertagna X, Jean C \& Martinez A 2004 Decreased expression of cyclic adenosine monophosphateregulated aldose reductase (AKR1B1) is associated with malignancy in human sporadic adrenocortical tumors. Journal of Clinical Endocrinology and Metabolism 89 3010-3019.

Lewis AE, Rusten M, Hoivik EA, Vikse EL, Hansson ML, Wallberg AE \& Bakke M 2008 Phosphorylation of steroidogenic factor 1 is mediated by cyclin-dependent kinase 7. Molecular Endocrinology 22 91-104.

Li Y, Choi M, Cavey G, Daugherty J, Suino K, Kovach A, Bingham NC, Kliewer SA \& Xu HE 2005 Crystallographic identification and functional characterization of phospholipids as ligands for the orphan nuclear receptor steroidogenic factor-1. Molecular Cell 17 491-502.

Lin L \& Achermann JC 2008 Steroidogenic factor-1 (SF-1, Ad4BP, NR5A1) and disorders of testis development. Sexual Development 2 200-209.

Looyenga BD \& Hammer GD 2006 Origin and identity of adrenocortical tumours in inhibin knockout mice: implications for cellular plasticity in the adrenal cortex. Molecular Endocrinology 20 2848-2863.

Luo X, Ikeda Y \& Parker KL 1994 A cell-specific nuclear receptor is essential for adrenal and gonadal development and sexual differentiation. Cell 77 481-490.

Madoux F, Li X, Chase P, Zastrow G, Cameron MD, Conkright JJ, Griffin PR, Thacher S \& Hodder P 2008 Potent, selective and cell penetrant inhibitors of SF-1 by functional ultra-high-throughput screening. Molecular Pharmacology 73 1776-1784.

Martinez A, Val P, Sahut-Barnola I, Aigueperse C, Veyssière G \& Lefrançois-Martinez AM 2003 SF-1 controls the aldose reductase akrlb7 gene promoter in transgenic mice through an atypical binding site. Endocrinology 144 2111-2120.

Matzuk MM, Finegold MJ, Mather JP, Krummen L, Lu H \& Bradley A 1994 Development of cancer cachexia-like syndrome and adrenal tumours in inhibin-deficient mice. PNAS 91 8817-8821.

Michalkiewicz E, Sandrini R, Figueiredo B, Miranda EC, Caran E, Oliveira-Filho AG, Marques R, Pianovski MA, Lacerda L, Cristofani LM et al. 2004 Clinical and outcome characteristics of children with adrenocortical tumours. An analysis of 254 cases from the International Pediatric Adrenocortical Tumour Registry. Journal of Clinical Oncology 22 838-845.

Morohashi K, Honda S, Inomata Y, Handa H \& Omura T 1992 A common trans-acting factor, Ad4-binding protein, to the promoters of steroidogenic P-450s. Journal of Biological Chemistry $\mathbf{2 6 7}$ 17913-17919.
Morohashi K, Tsuboi-Asai H, Matsushita S, Suda M, Nakashima M, Sasano H, Hataba Y, Li CL, Fukata J, Irie J et al. 1999 Structural and functional abnormalities in the spleen of an mFtz-F1 genedisrupted mouse. Blood 93 1586-1594.

Nomura M, Bärtsch S, Nawata H, Omura T \& Morohashi K 1995 An E box element is required for the expression of the Ad4bp gene, a mammalian homologue of ftz-fl gene, which is essential for adrenal and gonadal development. Journal of Biological Chemistry 270 7453-7461.

Pianovski MA, Cavalli LR, Figueiredo BC, Santos SC, Doghman M, Ribeiro RC, Oliveira AG, Michalkiewicz E, Rodrigues GA, Zambetti G et al. 2006 SF-1 overexpression in childhood adrenocortical tumours. European Journal of Cancer 42 1040-1043.

Ratcliffe J, Nakanishi M \& Jaffe RB 2003 Identification of definitive and fetal zone markers in the human fetal adrenal gland reveals putative developmental genes. Journal of Clinical Endocrinology and Metabolism 88 3272-3277.

Ribeiro RC, Sandrini F, Figueiredo B, Zambetti GP, Michalkiewicz E, Lafferty AR, DeLacerda L, Rabin M, Cadwell C, Sampaio G et al. 2001 An inherited p53 mutation that contributes in a tissue-specific manner to pediatric adrenal cortical carcinoma. PNAS 98 9330-9335.

Rilianawati , Paukku T, Kero J, Zhang FP, Rahman N, Kananen K \& Huhtaniemi I 1998 Direct luteinizing hormone action triggers adrenocortical tumourigenesis in castrated mice transgenic for the murine inhibin $\alpha$-subunit promoter/simian virus $40 \mathrm{~T}$-antigen fusion gene. Molecular Endocrinology 12 801-809.

Sadovsky Y, Crawford PA, Woodson KG, Polish JA, Clements MA, Tourtellotte LM, Simburger K \& Milbrandt J 1995 Mice deficient in the orphan receptor steroidogenic factor 1 lack adrenal glands and gonads but express P450 side-chain-cleavage enzyme in the placenta and have normal embryonic serum levels of corticosteroids. PNAS 92 10939-10943.

Sasano H, Shizawa S, Suzuki T, Takayama K, Fukaya T, Morohashi K \& Nagura H 1995 Ad4BP in the human adrenal cortex and its disorders. Journal of Clinical Endocrinology and Metabolism $\mathbf{8 0}$ 2378-2380.

Shibata H, Ikeda Y, Mukai T, Morohashi K, Kurihara I, Ando T, Suzuki T, Kobayashi S, Murai M, Saito I et al. 2001 Expression profiles of COUP-TF, DAX-1, and SF-1 in the human adrenal gland and adrenocortical tumors: possible implications in steroidogenesis. Molecular Genetics and Metabolism 74 206-216.

Shima Y, Zubair M, Ishihara S, Shinohara Y, Oka S, Kimura S, Okamoto S, Minokoshi Y, Suita S \& Morohashi K 2005 Ventromedial hypothalamic nucleus-specific enhancer of Ad4BP/SF-1 gene. Molecular Endocrinology 19 2812-2823.

Tamura M, Kanno Y, Chuma S, Saito T \& Nakatsuji N 2001 Pod$1 /$ Capsulin shows a sex- and stage-dependent expression pattern in the mouse gonad development and represses expression of Ad4BP/SF-1. Mechanisms of Development 102 135-144.

Val P, Martinez-Barbera JP \& Swain A 2007 Adrenal development is initiated by Cited 2 and $\mathrm{Wt} 1$ through modulation of Sf-1 dosage. Development 134 2349-2358.

Wang W, Zhang C, Marimuthu A, Krupka HI, Tabrizizad M, Shelloe R, Mehra U, Eng K, Nguyen H, Settachatgul C et al. 2005 The crystal structures of human steroidogenic factor-1 and liver receptor homologue-1. PNAS 102 7505-7510.

West AN, Neale GA, Pounds S, Figueredo BC, Rodriguez Galindo C, Pianovski MA, Oliveira Filho AG, Malkin D, Lalli E, Ribeiro R et al. 2007 Gene expression profiling of childhood adrenocortical tumours. Cancer Research 67 600-608.

Wilhelm D \& Englert C 2002 The Wilms tumour suppressor WT1 regulates early gonad development by activation of Sf1. Genes and Development 16 1839-1851.

Wilkin F, Gagné N, Paquette J, Oligny LL \& Deal C 2000 Pediatric adrenocortical tumours: molecular events leading to insulin-like growth factor II gene overexpression. Journal of Clinical Endocrinology and Metabolism 85 2048-2056. 
Wilson TE, Fahrner TJ \& Milbrandt J 1993 The orphan receptors NGFI-B and steroidogenic factor 1 establish monomer binding as a third paradigm of nuclear receptor-DNA interaction. Molecular and Cellular Biology 13 5794-5804.

Zanaria E, Muscatelli F, Bardoni B, Strom TM, Guioli S, Guo W, Lalli E, Moser C, Walker AP, McCabe ERB et al. 1994 An unusual member of the nuclear hormone receptor superfamily responsible for X-linked adrenal hypoplasia congenita. Nature 372 635-641.

Zubair M, Ishihara S, Oka S, Okumura K \& Morohashi K 2006 Two-step regulation of Ad4BP/SF-1 gene transcription during fetal adrenal development: initiation by a Hox-Pbx1-Prepl complex and maintenance via autoregulation by Ad4BP/SF-1. Molecular and Cellular Biology 26 4111-4121.
Zubair M, Parker KL \& Morohashi K 2008 Developmental links between the fetal and adult zones of the adrenal cortex revealed by lineage tracing. Molecular and Cellular Biology 28 7030-7040.

Zubair M, Oka S, Parker KL \& Morohashi K 2009 Transgenic expression of Ad4BP/SF-1 in fetal adrenal progenitor cells leads to ectopic adrenal formation. Molecular Endocrinology 23 1657-1667.

Received in final form 5 February 2010

Accepted 2 March 2010

Made available online as an Accepted Preprint 3 March 2010 